\title{
EVALUATING STEPHEN ZARLENGA'S TREATMENT OF HISTORICAL MONETARY THOUGHT
}

\author{
SIMON MOUATT: Senior Lecturer in Economics \\ Southampton Solent University \\ February 2008 simon.mouatt@solent.ac.uk
}

\begin{abstract}
Mainstream monetary theory has been subject to critiques from heterodox economists from the post-Keynesian and Marxist traditions yet, the monetary reform movement has been critical of political economists from all traditions for failing to identify the private issue of money as the central problem. In the United Kingdom, for instance, credit monies emanating from private banks constitute $97 \%$ of circulating currency (Shakespeare 2002). This paper reviews elements of the classically-derived mainstream view, and its critics, and evaluates the claims of monetary reformers. Stephen Zarlenga, for instance, in his historical study of the political economy of money, suggests that the (unnecessary) acceptance of the private creation of money precludes the possibility of a state-sanctioned 'money of account' (Zarlenga 2002). This cartalist notion of state-money, (perhaps mistakenly) citing Aristotelian origin, is seen as indispensable for effective monetary reform today. It is proposed that money is issued and established by law that is deliberately intended to exceed its intrinsic value, when functioning as a measure of commodities. Yet, this paper argues that these reformist ideas have been unfair in their historical treatment of Marx, Smith and Keynes, who had more sophisticated ideas on monetary matters than is credited. Notwithstanding, Zarlenga's (et al) work serves to illuminate an interesting arena for future research.
\end{abstract}

\section{KEY WORDS: Zarlenga, Monetary Reform, Monetary Theory, Smith, Keynes, Marx.}

\section{INTRODUCTION}

It is generally recognised that the private control of monies, in the modern era, has been increasing at the expense of the state. Several observers have noted, for instance, developments such as capital flow liberalisation, financial market deregulation and private credit creation (Strange; Amin; Cohen 1998; Strange). Still others point to political forces facilitating this transformation of global finance (Helleiner; Cerny 1998; Germain 1998). Within the globalisation discourse there has also been a debate about this erosion of state sovereignty, deriving from the suggestion that inter alia, state capacity to pursue independent fiscal and monetary policies has been diminished. The control of money is clearly a source of social power and, as accumulation diverts monies towards financial elites (from interest, fees and charges), the subsequent plutocracy may be to the detriment of the productive economy and society. Antecedents of these notions can be found in Lenin, Luxemburg and Hilferding, who noted the role of investment banking with the growth of the joint-stock firm and, in more recent times by several academics and monetary reformers (Hilferding 1910; Luxemburg 
1971; Kennedy 1995; Lenin 1996; Shakespeare 2002; El Diwany 2003). The argument put forward in Zarlenga's book is that this financial plutocracy has consciously obfuscated the (significant) research consideration of private money-issue, whether this manifests in the absence of historical records from the ancient world or from the deliberate politicisation of the economics discipline in the present. Zarlenga argues instead for the state reclamation of the 'money of account' issue capability, that also consciously chooses to refrain from the use of a commodity (with intrinsic value) since this is fraught with the continual misdirection of resources and (usually) the lack of state control. Zarlenga and other monetary reformers then argue for state-issued 'interest-free' money, for the purposes of public works or the spread of capital ownership, or even the comprehensive establishment of debt-free fiat monies (Kelso 1958; Kennedy 1995; Shakespeare 2002; El Diwany 2003).

\section{THE MAINSTREAM VIEW}

Monetary theorists, as Niebyl noted in his study of the classical period, have traditionally tended to explain the role of money in the productive economy by addressing particular conditions, pertaining to a defined historical context. Subsequently abstract notions or theories of money, which can be universally applied, are rare and subject to inconsistencies (Niebyl 1946). Notwithstanding, in the modern era a general Ricardian notion of money can be identified, at least in a crude form, which has exerted a major strategic influence on thinking in policy circles for two centuries, even though it is clear that not all classicists (and others since) adhered to these ideas. This mainstream approach presents a capitalist economic system that possesses a harmonious equilibrium, which can only be achieved if the authorities avoid misguided intervention and any market rigidities are removed. It is claimed that the unfettered operation of markets leads to an efficient allocation of resources and economic development. Furthermore, it is assumed that the 'trickle-down' theory ensures that the 'spoils' reach the marginalised. It is concluded that universal capitalism per se is the 'natural' historic social order that cannot be improved upon. Economic history is therefore complete.

In this context money and credit are seen as secondary - imperative for the functioning of capitalism but neutral, serving merely as a means of exchange, and not able to instigate or radically alter (at least in the long-term) the operation of economic activity or any real economic variables. ${ }^{i}$ Money is thus defined by its function and is perceived as created by the authorities, either directly by state issue or indirectly through the sanction of privately produced currency. Money then 'oils the wheels' of an essentially 'barter' economy - that determines the price ratios, whilst money per se is merely responsible for the nominal values. At the basis of these ideas is the (crude) quantity theory of money, derived from Locke, Hume and others, that claims when the money supply is increased ceteris paribus, the price level rises but relative price ratios are unaltered. The model assumes that money is issued exogenously (determined by forces outside the model), there is a stable velocity of circulation that is not influenced by endogenous factors, the volume of transactions are determined independently of the model, causality runs from 'money to price' (rather than the reverse) and the problems of adjustment to equilibrium are small - in other words markets 'clear' (Blaug 1995). It seems prima facie that the classicals viewed neutral money to be of secondary importance thus rendering the political consideration of the money-issue less worthy of debate.

Yet the mainstream view is problematic. If we consider the Walrasian equilibrium, for instance, with its (miraculous) set of price ratios, questions are raised. Are these sets of 
catallactic coincidences likely? If they are not, equilibrium is a redundant concept. Also, is there a new equilibrium established following each (whimsical) exogenous change in market forces? Furthermore, if money is merely used as a means of exchange, by enabling payment (in a barter-driven economy), a priori it becomes obsolete at the very time it is needed. Be that as it may, as a result of the 'reality' of the non-synchronisation of transactions, neoclassicals assert money is required that constitutes a (at least temporary) 'store of value'. This feature then becomes an additional and essential monetary function. The notion of nonsynchronisation is also normally used by neo-classicals as a raison d'etre for the historical origin of money (Meltzer 1998). Yet the mainstream, as Ingham has noted, has struggled to explain this origin of money within their limited theoretical framework (Ingham 2001). This is partly due to the microeconomic foundations of the neo-classical school that reduces economic activity to exchange ratios, determined by individual 'utility calculations'. In this barter economy, money is simply used as a device for exchange, and is considered to have evolved endogenously from the needs of market agents, an idea given form by Menger from the Austrian school and later backed by the Mises regression theorem (Menger 1871; Mises 1912). Here it is assumed that the most traded commodities became monies (Ingham 2001). The neo-classical account of money is therefore one of enabling exchange and the 'rational' agents have a common interest in its use. Yet the social relations imperative of money implies, as Ingham notes, the pre-existence of monetary institutions, in contradistinction to the neo-classical individualistic view of money origin (Ingham 2001). Zarlenga agrees with this idea of Ingham and further provides historical evidence to support the assertion that the authorities have been instrumental in the formation of currency (Zarlenga 2002; Hudson 2003). If this so, then it is a short step to accept, at least in theory, the latent statemanagement of a 'money of account', as a policy proposal in the present era.

Adam Smith (Smith 1776) had outlined money origin and explained its role in advancing the division of labour through transcending barter inefficiency. Smith argued that metallic money became the 'ideal' form and this led to state-minted coins based on weight. The state was able to provide legitimacy, harmonisation and efficiency to the weighing and assaying functions. In this sense the state had gained an indispensable role in the 'creation' of (commodity) money yet, Smith viewed the historical origin of money as market-driven. He then further explained the system of nominal prices, once coin denominations had been established. However as a neo-classical 'father', whilst positing specie money as exogenously (state) determined, he had little to say on the political implication of the paper 'private issue' e.g. credit monies issued to government and industry from the private investors at the newly created Bank of England. ${ }^{\text {ii }}$ Yet, this is a central concern of Zarlenga and the monetary reformers. As a member of the banking school Smith had recognised the tendency to hoard specie and argued that credit monies, such as bills of exchange, were subject to the law of the reflux, where monies find their way back to the financial intermediaries as contracts are cancelled. He had defended this view with reference to his real bills doctrine that maintained as long as credit monies were extended for purposes of 'real' economic activity, there would be no need to worry about over-issue or any inflationary impact. ${ }^{\text {iii }}$ Yet, for Smith, the nature of how the credit monies are formed appears to be irrelevant. Zarlenga hints that Smith's motive here was perhaps to support the profit aspirations of those that benefited most from the provision of credit (Zarlenga 2002).

Zarlenga also claims that Smith was a 'metallist' and further hints that he concealed, consciously or otherwise, the political significance of this 'private issue' of credit money. This is a little unfair towards Smith because, as Itoh and Lapavitsas note, Smith had recognised that specie was an inadequate 'store of value', since it was subject to the vagaries 
of mining, scarcity and balance of payments transfers, yet found no viable alternative commodity (Itoh 1999). Ironically the state, as well as private entities, is subject to these uncertainties and this undermines the potential quality of any state-issued (commodity) money - one of the points that Zarlenga wishes to make. In terms of the notion of the 'private-issue' of credit monies, in support of Zarlenga, Smith appears to make no reference to the political implications. Later on Ricardo and others, conversely, are concerned with the expansion of privately issued credit monies and, consequently advocated the state management of such phenomena. However, this was a concern with inflation not the private issue per se. ${ }^{\text {iv }}$ Zarlenga et al perhaps have more in common with Sir James Steuart, the late mercantilist, who had recognised the existence of an abstract 'money of account' and argued that specie was an inadequate money-form in this regard. He had further advocated the skills of a 'statesman' in order to ensure that the appropriate quantity of circulating (paper) credit money was available, endogenously derived from producer and consumer demand, since specie is hoarded (Itoh 1999). Yet Steuart also appeared to have no concern with the 'private issue' of monies, despite his ideas having contributed much towards heterodox thinking.

\section{KEYNES, CIRCUITISTS AND POST-KEYNESIANS}

Whilst challenging classical monetary thought, as Skidelsky notes, one view is that Keynes did not entirely escape the mainstream quantity theory tradition, consistently maintaining an exogenous money supply and (mostly) neutral money (Skidelsky 1995). ${ }^{\mathrm{v}} \mathrm{He}$ had, of course, outlined an under-employment equilibrium, that questioned Say's law and the ability of markets to 'clear' yet, this did not necessarily imply the non-neutrality of money, in the longterm at least, it just depended on the interpretation of the quantity theory used. ${ }^{\mathrm{vi}}$ For the classical purists it was a non-issue, since under-employment equilibrium simply did not exist. Keynes had felt that any under-employment was due to factors related to incomes, savings and investment and that, state policies (including monetary policy) could shift the consumption function towards a fully-employed equilibrium through the instigation of economic activity (Keynes 1936). ${ }^{\text {vii }}$ In his transmission mechanism, for instance, an exogenous increase in money led to a lower interest rate, then more investment and greater aggregate demand. At the new level of output there may (or may not) be an increased price level, depending on the shape of the aggregate supply curve. Yet, if demand policies were not pursued, or otherwise if in a fully employed economy, he viewed an exogenous change in money as neutral. Indeed, as Zarlenga points out, Keynes wrote an open letter to Roosevelt in 1933 where he warned against state-created money, likening it to 'trying to get fat by buying a larger belt'(Zarlenga 2002). Keynes presumably meant here that the US economy should be 'kick-started' by specific state-led demand measures that were deficit financed, through bond issue, and thus derived from the circulating currency. Simply producing fiat money would be ineffective and inflationary. Yet, does it really matter whether the financing for the 'demand-management' comes from government-issued money (monetized debt or debt-free fiat) or the coffers of private investors purchasing bonds? Keynes appears, as Zarlenga claims, to oppose the 'state issue' of money on principle, whilst supporting other features of state intervention. An alternative reading, however, could suggest that Keynes did not mind how the 'demand measures' were financed. The state-issue of a 'money of account', as monetary reformers argue, would mitigate the (political) influence of the private bankers and reduce the harmful effects of interest (Shakespeare 2002). It is also argued to be antiinflationary since it involves the 'creation and destruction' of debt, issued by the state at zero (or cost) interest, for purposes of public works or supported investment. Any output 
produced, therefore, would be free of any interest cost likely to lead to rising price pressures (Shakespeare 2002).

Be that as it may, are the comments of Stephen Zarlenga towards Keynes justified? On reflection it is important to remember that Keynes was clearly policy-driven and enjoyed the company of influential politicians. Consequently his primary analyses were likely to be fashioned by the realpolitik of the era. The Bank of England had supplied legal tender credit monies to the government since the $17^{\text {th }}$ century and, as Ingham contends, the subsequent expansion of 'negotiable or transferable' debt from the banking system as legal money had (and has) been unique and formative to capitalism (Ingham 2001). Perhaps, for Keynes, there was no apparent need to question the modus operandi of private money-issue since it had been reasonably successful over the years and it was a simple case of 'better the devil you know'. Yet, Keynes was a supporter of the cartalist view of historical money origin. He had, for instance, rejected the Menger view, the same position that Zarlenga takes, having been influenced by Knapp's State Theory of Money in his earlier work (Ingham 2001). An alternative explanation of his monetary thought is that he understood the potential role of the state in money-issue, but perhaps decided it was a politically un-achievable objective. He was instrumental, after-all, in the formation of (state) capital controls, in order to strengthen state capacity to pursue autonomous policies, within the Bretton Woods international system. He had also recommended 'cheap money' through the state management of interest rates. In his earlier work, of course, he had viewed interest rates as determined by his liquidity preference theory, where the demand for money (as a stock) interacted with an exogenous statedetermined money supply. In his later work, however, he maintained state policy-exogeneity for interest rates that then determined specific quantities of demand-driven endogenous money (created through bank accounting entries) or the use of pre-existing funds (Keynes 1937; Moore 2006).

Keynes' seminal analyses and comments have also spawned numerous post-Keynesian and circuitist approaches to money, that both assert the principle of endogenous creation, a central theme of the monetary reformers (Moore 1988; Davidson 1994; Graziani 2003). These heterodox notions derive from inter alia the 'finance motive' of Keynes that manifests in 'demand-led' credit expansion for purposes of investment, which then impacts output and employment. This suggests an (endogenous) ambiguity in Keynes' ideas on money. Yet, this could merely be seen as a reflection of the 'transmission mechanism' mentioned earlier, where monetary policy is used in conjunction with fiscal policy in an under-employment equilibrium. ${ }^{\text {viii }}$ For Keynes, as Skidelsky notes, money could still be exogenous and neutral in the long-term given increasingly stringent conditions (Skidelsky 1995). However a counterargument could suggest that the short-run is too long in this model and that, therefore, the 'finance-motive' is evidence of endogenous money in a long-run growth model. Money could also be viewed as non-neutral simply because production is instigated that otherwise would not take place. Batra for instance, in his empirical work, has discovered that money affects real variables across the cycle, when excess capacity is added to the classical model (Batra 2002).

Yet, there still appears to be no discourse that solely focuses on the key notion of the feasibility of a state issued 'money of account'. The French/Italian circuitists, however, have provided some useful ideas on the 'triangular' financial relationship between firms, households and banks, which is not needed in the neo-classical barter-economy view of money, and the post-Keynesians have emphasized that money creation is credit-driven by consumers and producers. Also, the concept of the creation and destruction of deposits, 
derived from the private banking infrastructure, is a key part of these schools of thought. This is similar to the view of the monetary reform movement that perceives money to be 'created out of nothing' with little or no government regulation. The existence of electronic depositbanking, of course, is seen to have further facilitated this development. Another important area of common ground, between reformers and the circuitists, is that they both claim money should be a 'token', with no intrinsic commodity value. Yet, whilst important studies have been instigated by these schools of thought, a discourse on the political implication of money-issue appears to be absent from the agenda. In this respect the monetary reform movement is correct to draw attention to the issue.

\section{MARXIAN VIEW OF MONEY}

Marx's view of money was essentially an extension of his (labour) law of value and, as a consequence, it was consistent with his overall method. Surplus value is realised in the market in the form of money and capital accumulation is also, of course, manifested in monetary nominal terms. Marx had also recognised that money was the instigator of economic activity and is therefore indispensable to production. Marx felt that in order to (socially) function, money needed to be a commodity. In his time this, of course, referred to gold - mined using human labour - that contained use-value (as money) and hence an exchange value. It is perhaps irrelevant whether or not the commodity money had commodity value other than its use value as money and that, therefore, accounting prices could be set in value-less units of currency in an abstract sense (as reformers suggest). However, whilst Marx appreciated the existence of abstract money that transfers (labour) value into price and real money that transfers price in to a 'concrete equivalent', containing the 'qualities' of money, it is assumed (and Zarlenga maintains) that Marx did not conceive of anything other than a commodity containing such qualities (Itoh 1999). In the modern era, conversely, we have a complete fiat money and credit money system that is not convertible to any other commodity and is fully legitimised and sustained by the modern state. However, in his discussion of the subject, Marx pointed out (p.119) that these types of monies cannot transcend the boundaries of state jurisdiction, whereas commodity money (e.g. gold) can (Marx 1970). This is clearly not the same as being unable to advocate the practical value of a state-sanctioned 'means of account', as Zarlenga contends. Furthermore Marx (p.79), with reference to the American colonies, clearly states that "gold and silver are not so necessary for the wealth of a nation, as the vulgar of all ranks imagine" (Marx 1970). ${ }^{\text {ix }}$

Notwithstanding Marx had, of course, theorised gold as money, with its value determined by the embodied labour content. Yet, in contrast to the quantity theorists, he felt that it was the 'value of money' determining the quantity in circulation rather than the quantity of money determining its value. If the value of gold falls more gold will be required to represent the same value and so, more circulating currency is needed. If gold production is cheaper, and is initially more profitable, then more gold is produced and exchanged. The extra demand pushes up prices through the system until a new equilibrium is reached with a new amount of circulating currency. In these cases the value of gold, prices and the volume of exchanges, determine the amount of money in circulation. Marx had demonstrated that quantity theorists (and often reformers) have causality the wrong way around (Brewer 1984).

In addition, Marx noted that convertible paper money can be created by the banking system which he refers to as a 'money sign' (Mandel 1987). In this instance the paper represents the money commodity nominally. This implies, therefore, that if any production of paper notes 
occurs in excess of the quantity of specie that it represents, ceteris paribus, there will be inflation providing it remains in circulation. Marx had outlined this difference between fiat monies and specie in this regard (Lapavitsas 1994). This appears, for paper money, to be an expression of the quantity theory although Marx's views were different. Marx was sympathetic to the banking school view that posited any excess of (credit) paper money, above the necessary quantity of commodity money backing (not used for economic activity), would return to the banking system - the 'law of the reflux' - or be hoarded, mitigating any inflationary impact (Itoh 1999).

Marx had also considered the activity of discounting bills of exchange by the banking sector, which he termed the credit system, economising on the use of money (Brewer 1984). However, he had not foreseen the growth of cheque clearing, which utilises bank deposits as money, and economises on paper money in circulation. In the modern era switch payments and direct debits use bank deposits in the same way. Modern economists view these bank deposits as money, unlike Marx. He was only interested in that which fulfilled the functions listed below, in his day (Brewer 1984). Conversely, monetary reformers are concerned with these payment operations since they facilitate the ability of private bankers to engage in credit creation, through reduced reserve requirements, and extract substantial tribute from the economy. This is not an oversight of Marx, of course, but merely a different historical context.

Marx had felt there was an order in the functioning of money, in the capitalist mode, that were respectively; the measure of value, the means of exchange (purchase) and money as money (for hoarding, payment and world money) (Itoh 1999). The 'measure of value' was dependent on the oscillations in the commodity value - in labour terms. Yet, Marx also talked about the 'standard of price' which referred to the actions of the state in setting rates of exchange between the commodity money and the official currency. In Marx's time an ounce of gold was set at $£ 317 \mathrm{~s} 10 \& 1 / 2 \mathrm{~d}$ (Brewer 1984). What is significant is that the accounting system of prices is abstract but has a social foundation, in terms of their commodity values, and is thus independent of the standard of price. The second function is the means of exchange. Here Marx is mindful of the velocity of circulation, characterised by constant movement. He recognised, in line with Ricardo, that the necessary quantity and velocity varied according to commodity values. Yet, Ricardo had thought that money was exogenously created, whereas Marx felt that meeting monetary requirements depended on the complexities of commodity money output and the existing hoards (Itoh 1999). Drawing money from hoards to meet any productive requirements is, of course, endogenous. Marx had partly accepted the Ricardian notion of money as a 'veil', since it was the circulating commodities, rather than the functioning of the money system, that determined prices and subsequent money quantity. However, as Itoh notes, Marx posited that money functioned outside of circulation and, in this sense, is not merely a 'veil' (Itoh 1999). For Marx the hoarding of money was an essential part of his overall political economy since the capitalist, through hoarding, was able to instigate (or not) new production whereas the proletariat was forced to sell his labour power. So Marx saw precautionary hoards as enabling capitalists to deal with market price fluctuations (of raw materials etc) in order to maintain the continuity of capitalist production.

Marx also presented the payment and world-money functions of money. During production and commercial transactions, of course, money is used to 'settle' any promises to pay. Commercial debt is subject to clearing, the exchange of one debt for another, but any balancing items can be settled during production periods. This economises on the function of 
money as a means of purchase. Marx had felt that the efficiency of the credit system (bills of exchange in his day) would determine the quantity of credit extended and he adhered to the idea of the 'cyclical' nature of credit money in the expansion of capitalist accumulation and, therefore, as non-neutral and endogenous (Itoh 1999). Finally, Marx had viewed commodity money as serving the function of world money, for purposes of international 'payment' for all sorts of things, in contrast to Ricardo who had viewed bullion as a pure means of exchange for commodities.

Yet, despite this theoretical discussion of money, did Marx have a position on the political implications of the private-issue? Zarlenga seems to think not. In the first volume of capital, however, Marx cites a passage from Martin Luther, who rants in prose about the sin of usury, which Luther maintains is analogous to robbery and murder (Marx 1976). This quote, in conjunction with the (above mentioned) reference to Bishop Berkeley, reveals Marx to be fully aware of the implications. Yet, perhaps, the crux of the matter is the location of social power - which Marx firmly places in the hands of the productive capitalists. This is the place, after all, where the value is created. For Marx, the financial system has, perhaps, simply manifested in a form that serves the needs of this capitalist mode of production. Furthermore, modern corporations have been developing their own payment systems, and banking operations, that has taken business away from the traditional banks. Indeed, this was foretold by Marx who had suggested that industrial capital would subjugate financial capital, as the economic system evolved (Marx 1971). In the wake of recent systemic financial crises, and the increasing vulnerability of commercial banks, this might prove to be prophetic.

\section{FURTHER COMMENTS ON LOST SCIENCE CFebruary 2008 Southampton Solent University}

A central theme of Stephen Zarlenga's 'Lost Science', that money 'established by law' can be traced to Aristotle, is not entirely safe. Geoffrey Ingham (Cambridge), for instance, claims that Aristotle is the founding father of commodity money theories - the exact opposite (Ingham 2001). Zarlenga and Hudson, backed by historical account, have convincingly outlined how the state (and/or temple) instigation and management of ancient monetary systems was paramount yet, this does not make Aristotle the father of the notion (Zarlenga 2002; Hudson 2003). Ingham had based his (contradictory) claim on the work of Joseph Schumpeter in 1954, which cited an ambiguity in Aristotle. Whilst Aristotle had clearly mentioned money 'established by law' he had, paradoxically, also explained how barter changed to a monetary economy through the use of a common commodity. This is similar to the Smith/Marx/Menger view, who Zarlenga refutes. This means (if Schumpeter was correct) that Aristotle can be named as the father of the cartalist and the mainstream view of moneyorigin and, furthermore, that his ideas are not that different to Smith, Menger or Marx. All three recognised, of course, that the state (and law) quickly assumes a money management role once money has originated. Marx illustrates (Capital: Vol 1, p.151) that Aristotle had viewed the 'money-form' of a commodity as a 'more developed' aspect of the basic commodity (Marx 1976). ${ }^{\mathrm{x}}$ Furthermore Marx, in his Critique of Political Economy (p.117 footnote), claims that Aristotle was a sharper monetary theorist than Plato but talks about the development of commodity money that is intrinsically useful - derived from barter between communities (Marx 1970). Schumpeter further claims that Plato, though not a great money theorist, had described the money-role as a 'symbol' and, also, had a distaste for gold/silver currency suggesting that he was a better forerunner of the system Zarlenga proposes than Aristotle (Schumpeter 1954). Zarlenga is not wrong as such but, arguably, needs to 'set the record straight' for the purposes of academic integrity and any second edition. Yet, it has to 
be said, Zarlenga has presented a set of ideas that we desperately need to consider if we are to transform this destructive debt-based money system that we all suffer from.

\section{REFERENCES}

Amin, S. (1997). Capitalism in an Age of Globalisation. Guildford, Zed.

Batra, R. (2002). "Neutrality and Non-Neutrality of Money in a Classical-Type Model." Political Economic Review 7(3): 489.

Blaug, M. (1995). Why is the Quantity Theory of Money the Oldest Surviving Theory in Economics? The Quantity Theory of Money - From Locke to Keynes and Friedman. G. Wood. Chippenham, Edward Elgar.

Brewer, A. (1984). A Guide to Marx's Capital. Cambridge, Cambridge University Press.

Cerny, P. G. (1998). "Politicising International Finance." Millenium: Journal of International Studies 27(No 2).

Cohen, B. J. (1998). The Geography of Money. London, Cornell University Press.

Davidson, P. (1994). Post-Keynesian Macroeconomic Theory. Aldershot, Edward Elgar.

El Diwany, T. (2003). The Problem with Interest 2nd Ed. Birmingham, Kreatoc.

Germain, R. D. (1998). The International Organisation of Credit: States and Global Finance in the World-Economy. Cambridge, Cambridge University Press.

Graziani, A. (2003). The Monetary Theory of Production, Cambridge University Press.

Helleiner, E. (1994). States and the Re-emergence of Global Finance: From Bretton Woods to the 1990's, Cornell University Press.

Hilferding, R. (1910). Finance Capital, Routledge.

Hudson, M. (2003). The Creditary/Monetarist Debate in Historical Perspective. The State, The Market and the Euro. E. N. S. Bell. London, Edward Elgar.

Ingham, G. (2001). "Fundamentals of a Theory of Money: Untangling Fine, Lapavitsas and Zelizer." Economy and Society.

Itoh, M. L., Costas (1999). The Political Economy of Money and Finance. Chippenham, Macmillan.

Kelso, L. O. A., Mortimer. J (1958). The Capitalist Manifesto. New York, Random House.

Kennedy, M. (1995). Inflation and Interest Free, New Society Publisher.

Keynes, J. M. (1936). The General Theory of Employment, Interest and Money, Macmillan. 
Keynes, J. M. (1937). "Alternative Theories of the Rate of Interest." Economic Journal 47(186): p.241-252.

Lapavitsas, C. (1994). "The Banking School and the Monetary Thought of Karl Marx." Cambridge Journal of Economics 18: 447-461.

Lenin, V. (1996). Imperialism: The Highest Stage of Capitalism. Bristol, Pluto.

Luxemburg, R. (1971). The Accumulation of Capital. London, Routledge.

Mandel, E. (1987). Karl Marx. Marxian Economics. M. M. a. P. N. John Eatwell. Hong Kong, Macmillan.

Marx, K. (1970). A Contribution to the Critique of Political Economy. Union of Soviet Socialist Republics, Lawrence \& Wishart.

Marx, K. (1971). Theories of Surplus Value: Part Three. Moscow, Progress.

Marx, K. (1976). Capital: Volume One. St Ives, Penguin.

Meltzer, A. H. (1998). What is Money? Money, Prices and the Real Economy. G. Wood. Bodmin, Edward Elgar.

Menger, C. (1871). Principles of Economics. Online Edition, Ludvig von Mises Institute.

Mises, L. v. (1912). The Theory of Money and Credit.

Moore, B. (1988). Horizontalists \& Verticalists: The Macroeconomics of Credit Money. New York, Cambridge University Press.

Moore, B. (2006). Shaking the Invisible Hand: Complexity, Endogenous Money and Exogenous Interest Rates, Palgrave, Macmillan.

Niebyl, K. H. (1946). Studies in the Classical Theories of Money. New York, Columbia University Press.

Schumpeter, J. A. (1954). History of Economic Analysis. Guildford, Routledge.

Shakespeare, R. C., Peter (2002). Seven Steps to Justice. Chippenham, New European Publications.

Skidelsky, R. (1995). J.M. Keynes and the Quantity Theory of Money. The Quantity Theory of Money - From Locke to Keynes and Friedman. G. Wood. Chippenham, Edward Elgar.

Smith, A. (1776). The Wealth of Nations.

Strange, S. (1988). States and Markets. London, Pinter.

Strange, S. (1998). Mad Money. Guildford, Manchester University Press. 


\footnotetext{
i Blaug notes that there is also the notion of 'superneutrality', adhered to by the monetarist school, that claims the neutrality of money even under specific conditions of an increasing rate of growth of money supply something that Hume had not agreed with Blaug, M. (1995). Why is the Quantity Theory of Money the Oldest Surviving Theory in Economics? The Quantity Theory of Money - From Locke to Keynes and Friedman. G. Wood. Chippenham, Edward Elgar.
}

${ }^{i i}$ Niebyl noted that this central bank role increased as mercantile credit declined Niebyl, K. H. (1946). Studies in the Classical Theories of Money. New York, Columbia University Press.

iii This also meant that Smith did not adhere to the quantity theory of Hume.

iv Supporters of the Ricardo view formed the currency school.

${ }^{v}$ Liquidity preference theory, for instance, assumes an exogenous money supply. Keynes did, however, have different views on the velocity of money developed in his Treatise on Money.

vi The under-employment equilibrium could be regarded, for instance, as a transitory period (short-term) where adjustment occurs. Keynes certainly viewed money as non-neutral during this time.

vii Evidence for this can be found in Keynes' support for monetary reform, alongside Wicksell and Fisher, where they advocated state monetary policy (free from the vagaries of gold) in order to stablise the trade cycle Skidelsky, R. (1995). J.M. Keynes and the Quantity Theory of Money. The Quantity Theory of Money - From Locke to Keynes and Friedman. G. Wood. Chippenham, Edward Elgar.

viii Keynes held, of course, that productive investors tended to be reasonably 'interest inelastic' suggesting that easy money itself was insufficient without demand management policies. This explains why Keynesians have favoured fiscal policy over monetary policy.

ix Marx even quotes Benjamin Franklin (p.56), popular with monetary reformers, as a supporter of the 'law of value' for determining the standard of price for silver Marx, K. (1970). A Contribution to the Critique of Political Economy. Union of Soviet Socialist Republics, Lawrence \& Wishart.

${ }^{x}$ Marx also notes (p.151) that Aristotle had recognized that (for exchange) commodities needed to be 'qualitatively equated', in order to be 'commensurable magnitudes', but did not recognise labour content as a common substance Marx, K. (1976). Capital: Volume One. St Ives, Penguin. 